\title{
Technology for Treating Oily Wastewater Derived from Various Industries: A Review Paper
}

\author{
Sri Martini ${ }^{\mathrm{a}, 1, *}$, Mira Setiawati ${ }^{\mathrm{b}, 2}$ \\ ${ }^{a}$ Department of Chemical Engineering, Faculty of engineering, Universitas Muhammadiyah Palembang, 13 ulu, Palembang, Indonesia \\ ${ }^{\mathrm{b}}$ Department of Civil Engineering, Faculty of engineering, Universitas Muhammadiyah Palembang, 13 ulu, Palembang, Indonesia \\ ${ }^{1}$ srimartini79@gmail.com*; ${ }^{2}$ mirasetiawati060781@gmail.com \\ * corresponding author
}

ARTICLE INFO

Article history

Received November 13, 2020

Revised January 13, 2021

Accepted January 14, 2021

Keywords

Adsorption

Coagulation

Integrated treatment

Membrane filtration

Oily wastewater

\section{ABSTRACT}

The increasing number of industrial sectors has resulted in more and more contaminated water and wastewater containing various harmful pollutants including oil compound. Less treated or untreated oily wastewater could give a serious threat to both human health and environmental sustainability. Therefore, the appropriate treatment methods such as membrane filtration, coagulation/flocculation, biological treatment, adsorption, and relevant integrated methods have to be implemented well to enhance the quality of those wastewaters before they are flowed into the final disposal place. This effort will endorse the success of waste management and circular economy system by recycling unwanted industrial by-product including wastewater, so it can be reused for further productive purposes.

\section{Introduction}

Industrial development has contributed directly and indirectly to the increase in oily wastewater production. This unwanted by-product refers to oil and water mixture in any composition along with other harmful contaminants, so the water cannot be used any longer for productive process unless it is treated properly to reach certain standard of characteristics [1]. Generally, apart from other contaminants, wastewaters produced by oil manufacturer and other related industries contain some fats, waxes, or mineral oil solution endangering the environmental sustainability as well as human health to some extent $[2,3]$.

Theoretically, oil can be classified into some forms including petroleum oil, mineral oil, animal oil, and vegetable oil or plant-based oil [1]. There are various industries produce oily wastewaters in different quality levels. Petroleum refinery company, edible oil manufacturers, food and beverage, restaurant industry, and cooling and heating industries are several prominent industries that could generate a huge amount of oily wastewater resulted from some processes like production, refining, storage, and transportation $[2,3]$.

\section{Oily wastewater and industry}

Even though the industrial wastewater itself is a challenge for protecting environment, the growing industry is important for both economic growth and human life. Edible oil, for example, has been an important part of human life for being used in many purposes like cooking, cosmetic, and pharmacy products. Edible oil industries such as palm oil, canola oil, and olive oil result in oily wastewater containing harmful contaminants that need to be regulated in terms of its acceptable discharge standard before its final disposal to the final open place [3]. 


\subsection{Palm oil industry}

Palm oil producers are growing fast in several countries such as Indonesia, Malaysia and Nigeria resulting in challenging environmental issues to the countries due to high organic and non-organic contaminants in palm oil mill effluent (POME) [4]. POME as a by-product of palm oil manufacturing process is thick viscous liquid waste having foul odor with high concentration of COD, BOD and oil and grease $[4,5]$. Therefore, governments or other related institutions have to standardize the POME discharge. Table 1 illustrates the example of allowable values of POME to be discharged to the open waters [4].

Table 1. POME characteristics and acceptable discharge standard

\begin{tabular}{ccc}
\hline Parameters & Raw POME & POME discharge standard \\
\hline Temperature $\left({ }^{\circ} \mathrm{C}\right)$ & $80-90$ & 45 \\
BOD $(\mathrm{mg} / \mathrm{L})$ & 25,000 & 100 \\
COD $(\mathrm{mg} / \mathrm{L})$ & 50,000 & - \\
Oil $(\mathrm{mg} / \mathrm{L})$ & 4,000 & 50 \\
Total Solids $(\mathrm{mg} / \mathrm{L})$ & 40,500 & - \\
$\mathrm{pH}$ & 4.7 & $5-9$ \\
Total Kjehdal Nitrogen $(\mathrm{mg} / \mathrm{L})$ & 750 & 200 \\
\hline
\end{tabular}

\subsection{Canola oil industry}

Canola oil made from rapeseed plant is widely used for cooking oil and as an additive substance for candles, inks and medicinal products [5]. In its production process, the rapeseed plant is slightly heated, crushed and extracted using hexane, then refined using water precipitation and organic acid to remove gums, and then deodorized by steam distillation. Despite having lower values of COD, TOC, suspended solid and oil and grease, canola oil effluent still has to be purify before its final disposal. A study which investigated canola oil effluent treatment reported some characteristics of raw canola oil wastewater as stated in table 2 [6].

Table 2. Characteristics of raw canola oil wastewater

\begin{tabular}{cc}
\hline Parameter & Range \\
\hline COD $(\mathrm{mg} / \mathrm{L})$ & 330 \\
TOC $(\mathrm{mg} / \mathrm{L})$ & 90 \\
Oil $(\mathrm{mg} / \mathrm{L})$ & 250 \\
$\mathrm{pH}$ & 9 \\
\hline
\end{tabular}

\subsection{Olive oil}

Olive oil is mostly produced by manufacturers located in the Mediterranean countries. This oil is known as the healthiest cooking oil as it offers some advantageous points in terms of health perspective. Other than that, olive oil is also useful for cosmetics production and other personal needs such as soap and shampoo as it is rich in antioxidant elements. However, its oily wastewater could contain high level of harmful pollutants, as illustrating in Table 3, yielding poor quality of the wastewaters $[7,8]$.

Table 3. Characteristics of raw olive oil mill wastewater

\begin{tabular}{cc}
\hline Parameter & Range \\
\hline $\mathrm{pH}$ & $4-5$ \\
$\mathrm{TOC}(\mathrm{mg} / \mathrm{L})$ & $1800-3200$ \\
$\mathrm{COD}(\mathrm{mg} / \mathrm{L})$ & $129000-183000$ \\
Conductivity $(\mathrm{mS} / \mathrm{cm})$ & $16-32$ \\
Oil $(\mathrm{mg} / \mathrm{L})$ & $5200-7800$ \\
Total phosphorus $(\mathrm{mg} / \mathrm{L})$ & $350-830$ \\
\hline
\end{tabular}

\subsection{Petroleum industry}

To date, petroleum industry valorizing crude oil to become higher valuable fuel products for various applications through refining process has been the main source of industrial oily wastewater. This is because, apart from the effort of creating alternative green energy sources, crude oil and other fossil fuel still act as the main source of energy. This phenomena has resulted in a massive amount of petroleum refinery wastewater having detrimental influence on both environment and 
living creatures due to its toxic contents like oil, hydrocarbons, sulfides, ammonia and large quantities of inorganic salts [9] as stated in Table 4 [10-12].

Table 4. Characteristics of raw petroleum refinery wastewater

\begin{tabular}{ccc}
\hline Parameters & $\begin{array}{c}\text { Average discharge } \\
\text { values }\end{array}$ & $\begin{array}{c}\text { Acceptable discharge } \\
\text { standard }\end{array}$ \\
\hline COD $(\mathrm{mg} / \mathrm{L})$ & 3340 & 140 \\
BOD $(\mathrm{mg} / \mathrm{L})$ & 280 & 17 \\
Oil $(\mathrm{mg} / \mathrm{L})$ & 200 & 23 \\
pH & 10.6 & 6.2 \\
Temperature $\left({ }^{\circ} \mathrm{C}\right)$ & 41 & 22 \\
Sulfide $(\mathrm{mg} / \mathrm{L})$ & 38 & 0 \\
Phosphorus $(\mathrm{mg} / \mathrm{L})$ & 97 & 0 \\
\hline
\end{tabular}

\subsection{Restaurant industry}

Restaurant industry cannot be separated from urban development as it is main part of modern lifestyle for the community. This industry can have a significant amount of oily wastewater containing high oil and grease particles generated from its operational activities such as washing kitchen utensils, cleaning and cooking food materials [13]. In many developing countries, the oily wastewater generated by restaurant industry mostly flows into foul sewers. It would lead to public sewage treatment plants that can cause drain pipes blockage, bad odor, and harmful open waters if left less or untreated [14]. Table 5 illustrates the common characteristics detected in some restaurant wastewaters [13].

Table 5. Characteristics of raw restaurant oily wastewater

\begin{tabular}{cc}
\hline Parameters & Range \\
\hline COD $(\mathrm{mg} / \mathrm{L})$ & $750-6800$ \\
BOD $(\mathrm{mg} / \mathrm{L})$ & $600-2500$ \\
Oil $(\mathrm{mg} / \mathrm{L})$ & $500-4700$ \\
$\mathrm{pH}$ & $6.1-8$ \\
Suspended solid $(\mathrm{mg} / \mathrm{L})$ & $250-650$ \\
$\mathrm{NH}_{2}-\mathrm{N}(\mathrm{mg} / \mathrm{L})$ & $4.8-10.4$ \\
\hline
\end{tabular}

\section{Existing Technology for Oily Wastewater Treatment}

The untreated or less treated oily wastewater can endanger public health and ecological systems due to its hazardous components. Other than oil and grease, oily wastewaters may also contain suspended and dissolved solids, phenol, heavy metals, dyes, and other harmful particles [15]. Therefore, proper treatment processes for oily wastewater are needed to produce wastewater that meets the regulatory standards. Several existing technologies can be implemented to increase the quality of those oily wastewaters such as air flotation, membrane filtration, advanced oxidation, and adsorption.

\subsection{Air flotation}

For oily wastewater treatment, this method can be applied for reducing the amounts of fat, oil and grease by bubbling air through wastewater tank or pond in order to increase the specific gravity difference between pollutant particles and water [16]. In this process, suspended particles and oil globules can be floated to the wastewater surface to be removed by further skimming. There are some techniques of air flotation like dissolved air flotation (DAF), dispersed air flotation (DispAF) and electro-flotation. For DAF, wastewater is saturated under pressure with air generated by granular media filtration. Then, the pressure is released through needle valves into flotation cells resulting in air bubbles having about $30-120 \mu \mathrm{m}$ in diameter [17]. For DispAF technique, air bubbles are produced through the pores of sintered glass disks with diameter ranging from 75 to 655 $\mu \mathrm{m}$ [18], while electro-flotation process involving electrolysis of water used with bubbles that is produced at the electrodes having diameters ranging from 22 to $50 \mu \mathrm{m}$ [19].

\subsection{Membrane separation process}

Membrane separation is an advanced filtration process mainly driven by the pressure difference as an average value of inlet and outlet pressure, named trans membrane pressure. Other parameters 
that affect the effectiveness of membrane filtration processes are cross flow velocity, temperature, $\mathrm{pH}$, oil, and salt concentration $[20,21]$. There are several types of membrane that commonly applied in wastewater treatment plants as described in Table 6 [22].

Table 6. Membrane characteristics

\begin{tabular}{|c|c|c|c|c|c|}
\hline $\begin{array}{c}\text { Membrane } \\
\text { type }\end{array}$ & Structure & Driving force & Mechanism & Material & $\begin{array}{c}\text { Polar } \\
\text { Tendency }\end{array}$ \\
\hline Electrodialysis & $\begin{array}{l}\text { Electrostatically } \\
\text { charged membrane }\end{array}$ & $\begin{array}{l}\text { Electrical } \\
\text { potential }\end{array}$ & $\begin{array}{l}\text { Electrostatic } \\
\text { diffusion }\end{array}$ & $\begin{array}{c}\text { Styrene/ } \\
\text { Vinylpyridene, } \\
\text { Divinyl benzene- }\end{array}$ & - \\
\hline Microfiltration & $\begin{array}{c}\text { Symmetric } \\
\text { microporous }(0.02- \\
10 \mu)\end{array}$ & $\begin{array}{l}\text { Pressure, } 1 \text { - } 5 \\
\text { atm }\end{array}$ & Sieving & $\begin{array}{c}\text { Polypropylene, } \\
\text { Polyethylene, } \\
\text { Polycarbonate, } \\
\text { Ceramic }\end{array}$ & Non polar \\
\hline Ultrafiltration & $\begin{array}{c}\text { Asymmetric } \\
\text { microporous }(1-20 \\
\mathrm{nm})\end{array}$ & $\begin{array}{c}\text { Pressure } 2-10 \\
\text { atm }\end{array}$ & Sieving & $\begin{array}{c}\text { Polysulfone, } \\
\text { Dynel, } \\
\text { Cellulose acetate, } \\
\text { Polyvinylidene } \\
\text { fluoride }\end{array}$ & Non polar \\
\hline Nanofiltration & $\begin{array}{c}\text { Asymmetric } \\
\text { microporous }(0.01 \text { - } \\
5 \mathrm{~nm})\end{array}$ & $\begin{array}{c}\text { Pressure } 5 \text { - } 50 \\
\text { atm }\end{array}$ & Sieving & $\begin{array}{l}\text { Polyvinylidene } \\
\text { fluoride }\end{array}$ & Polar \\
\hline $\begin{array}{l}\text { Reverse } \\
\text { osmosis }\end{array}$ & $\begin{array}{c}\text { Asymmetric } \\
\text { homogeneous skin, } \\
\text { microporous support }\end{array}$ & $\begin{array}{c}\text { Pressure } 10 \text { - } \\
100 \mathrm{~atm}\end{array}$ & $\begin{array}{l}\text { Solution } \\
\text { diffusion }\end{array}$ & $\begin{array}{c}\text { Cellulose acetate, } \\
\text { Polyamide, } \\
\text { Nylon }\end{array}$ & Polar \\
\hline
\end{tabular}

Membrane filtration has some excellent points such as high contaminant removal percentage, automatic operation system, molecule separation based on manageable size dismissal, no specific chemical needed, and moderate skilled operators [23-26]. However, high loading oily wastewaters can lead quickly to membrane fouling caused by oil and other pollutant particles depositing onto membrane surface or membrane pores. When this happens, the performance of the membrane will decrease leading to less and less volume of permeate. Some models can be used to describe the fouling mechanism occurring on membrane pores during filtration. Hermia's models consisting of cake formation, intermediate pore blocking, standard pore blocking and complete pore blocking model are well acceptable models used for fouling mechanism analysis as described in Table 7 [2730].

Table 7. Hermia's models and blocking mechanism

\begin{tabular}{|c|c|c|c|}
\hline Blocking mechanism & n -value & $\begin{array}{c}\text { Fouling mechanism } \\
\text { illustration }\end{array}$ & Hermia's models \\
\hline Cake layer formation & 0 & & $\frac{1}{J^{2}}=\frac{1}{J_{0}^{2}}+K t$ \\
\hline Intermediate pore blocking & 1 & & $\frac{1}{J}=\frac{1}{J_{0}}+K A t$ \\
\hline Standard pore blocking & 1.5 & & $\frac{1}{J^{0.5}}=\frac{1}{J_{0}^{0.5}}+K t$ \\
\hline Complete pore blocking & 2 & & $\operatorname{Ln}(J)=\operatorname{Ln}\left(J_{0}\right)-K t$ \\
\hline
\end{tabular}

\subsection{Adsorption process}

Adsorption is the adhesion process of atoms, ions or molecules from a gas, liquid, or dissolved solid to adsorbent surface when they are in contact for specific time [31]. This process could take place through physical and chemical ways. While physical adsorption is the existence of interparticle bonds between adsorbate and adsorbent reversibly, chemical adsorption experiences stronger ion or molecule aggregation by electron exchange irreversibly. 
Activated carbon (AC) is one of the most prominent types of practical adsorbent used in adsorption process. However, the regeneration cost of the saturated $\mathrm{AC}$ is relatively expensive. This condition has opened the curiosity to explore a variety of low cost adsorbents derived from some agricultural and other organic wastes as displayed in Table 8. Those natural organic materials have several benefits including better economic value, simple usage, reliable availability, and high biodegradation [32-34].

In order to increase the performance of those adsorbent materials, activation process such as chemical impregnation, esterification, and carbonization could be conducted as well as combining adsorption to other treatment methods [42]. Several factors affecting the efficiency and effectiveness of the adsorbent to remove oil particle from oily wastewater should be noticed including sorbent dosage, sorbent bed height, sorbent particle size, feed flow rate, initial concentration of oily solution, $\mathrm{pH}$, temperature, and contact time between adsorbent and adsorbate [1].

Table 8. Natural organic-based adsorbent for oil content removal from industrial wastewater

\begin{tabular}{|c|c|c|c|}
\hline Adsorbent & $\begin{array}{c}\text { Oily wastewater } \\
\text { derived from industry }\end{array}$ & Results & Ref. \\
\hline $\begin{array}{l}\text { Modified Barley } \\
\text { straw }\end{array}$ & Canola oil & $\begin{array}{c}\text { Adsorption capacity: } 44 \mathrm{mg} / \mathrm{g} \text {, adsorbent dosage: } 1.3 \\
\mathrm{~g} / \mathrm{L} \text {, oil removal efficiency: } 94 \% \text {, sorption time: } 60 \\
\text { min, } \mathrm{pH}: 6.0-8.0\end{array}$ & [35] \\
\hline Natural wool fibers & Diesel oil & $\begin{array}{l}\text { Adsorption capacity: } 430 \mathrm{mg} / \mathrm{g}, \text { adsorbent dosage: } \\
0.04 \mathrm{~g} / \mathrm{L} \text {, oil removal efficiency: } 95 \% \text {, sorption time: } \\
30 \mathrm{~min}, \mathrm{pH}: 8.0\end{array}$ & [36] \\
\hline Sugarcane bagasse & Emulsified machine oil & Adsorption capacity: $680 \mathrm{mg} / \mathrm{g}$, sorption time: $60 \mathrm{~min}$ & [37] \\
\hline Walnut shell & $\begin{array}{l}\text { Standard } \\
\text { mineral oil }\end{array}$ & Adsorption capacity: $560 \mathrm{mg} / \mathrm{g}$, sorption time: $60 \mathrm{~min}$ & [38] \\
\hline Walnut shell & vegetable oil & $\begin{array}{l}\text { Adsorption capacity: } 0.58 \mathrm{~g} / \mathrm{g} \text {, Sorption time: } 60 \mathrm{~min} \\
\text { Adsorbent dosage: } 2 \mathrm{~g} / \mathrm{L} \text {, sorption time: } 30 \mathrm{~min} \text {, oil }\end{array}$ & [38] \\
\hline Chitosan (flake) & Palm oil mill & $\begin{array}{c}\text { removal efficiency: } 99 \% \text {, mixing rate: } 100 \mathrm{rpm}, \mathrm{pH}: \\
4.0-5.0\end{array}$ & [39] \\
\hline Cotton grass fiber & Petroleum Refinery & $\begin{array}{l}\text { Adsorption capacity: } 1700 \mathrm{mg} / \mathrm{g} \text {, adsorbent dosage: } 1 \\
\text { g/L, oil removal efficiency: } 89 \% \text {, sorption time: } 120 \\
\text { min }\end{array}$ & [40] \\
\hline Chitosan (powder) & Palm oil mill & $\begin{array}{l}\text { Adsorbent dosage: } 0.5 \mathrm{~g} / \mathrm{L} \text {, sorption time: } 30 \mathrm{~min} \text {, oil } \\
\text { removal efficiency: } 99 \% \quad \mathrm{pH}: 4.0-5.0\end{array}$ & [39] \\
\hline $\begin{array}{l}\text { Palm shell activated } \\
\text { carbon }\end{array}$ & Palm oil mill & $\begin{array}{l}\text { Adsorption capacity: } 33 \mathrm{mg} / \mathrm{g} \text { adsorbent dosage: } \\
80 \mathrm{~g} / \mathrm{L} \text {, sorption time: } 24 \mathrm{~h} \text {, oil removal efficiency: } \\
85 \% \mathrm{pH}: 4.5\end{array}$ & \\
\hline $\begin{array}{l}\text { Palm shell carbon } \\
\text { magnetic composite }\end{array}$ & Palm oil mill & $\begin{array}{l}\text { rption capacity: } 100 \mathrm{mg} / \mathrm{g}, \quad \text { adsorbent dosage: } 80 \mathrm{~g} / \mathrm{L} \text {, } \\
\text { oil removal efficiency: } 90 \% \text {, sorption time: } 24 \mathrm{~h},\end{array}$ & [41] \\
\hline Sago bark & Palm oil mill & $\begin{array}{c}\text { Adsorbent dosage: } 17.5 \mathrm{~g} / \mathrm{L} \text {, sorption time: } 30 \mathrm{~min} \text {, } \\
\text { oil removal efficiency: } 45 \%, \mathrm{pH}: 4\end{array}$ & [42] \\
\hline Bentonite & Palm oil mill & $\begin{array}{l}\text { Adsorbent dosage: } 10 \mathrm{~g} / \mathrm{L} \text {, sorption time: } 30 \mathrm{~min} \text {, Oil } \\
\text { removal efficiency: } 90 \%, \mathrm{pH}: 4.0-5.0\end{array}$ & [39] \\
\hline Silkworm cocoon & Vegetable oil & $\begin{array}{l}\text { Adsorption capacity: } 1500 \mathrm{~m} \mathrm{~g} / \mathrm{g} \text {, sorption time: } 10 \\
\text { min, oil removal efficiency: } 54 \%\end{array}$ & [43] \\
\hline Eucalyptus bark & Petroleum refinery & $\begin{array}{l}\text { Adsorbent dosage: } 10 \mathrm{~g} / \mathrm{L} \text {, sorption time: } 100 \mathrm{~min} \text {, oil } \\
\text { removal efficiency: } 91 \%, \mathrm{pH}: 3\end{array}$ & [44] \\
\hline
\end{tabular}

\subsection{Coagulation/flocculation}

Coagulation and flocculation utilize chemicals to create a rapid-settling aggregate out of finely divided suspension in contaminated water and wastewater leading to elimination of trace organic contaminants. Some stages including destabilization, entrapment, and aggregation or colloids binding processes could create larger or heavier flock particles. As a consequence, those particles could be easily removed by subsequent settling and filtration [45]. The common mechanism of coagulation/flocculation process is illustrated in figure $1[30]$. 


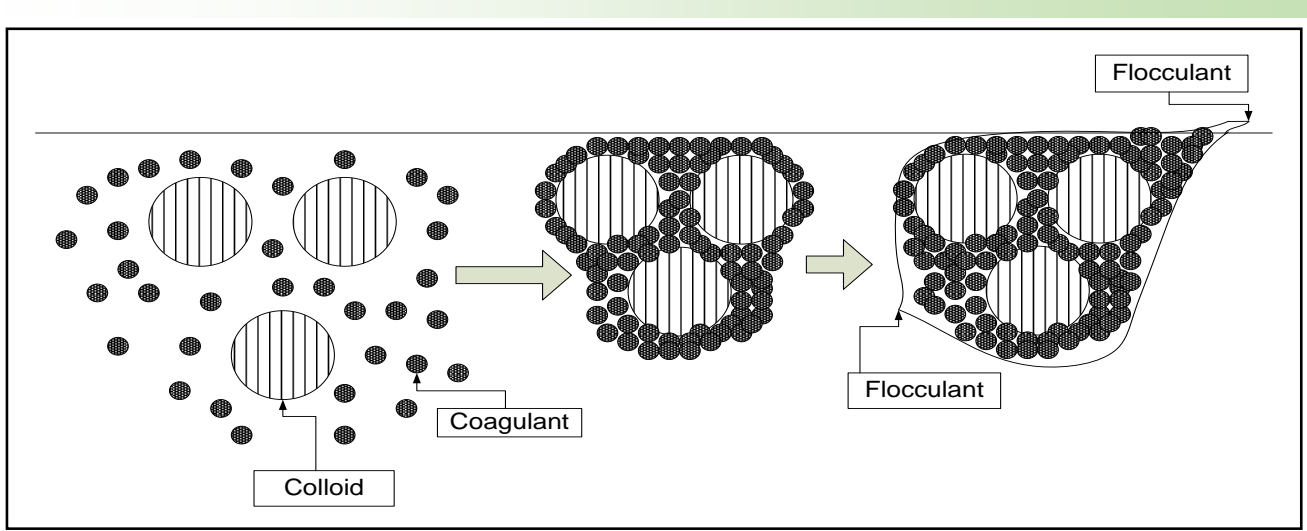

Fig. 1.The mechanism of coagulation/flocculation

There are various coagulants or flocculants available for this purpose such as lime, magnesium, aluminum salts, calcium oxide and aluminum sulphate [46, 47]. Regarding wastewaters containing oil and grease particles, coagulation and flocculation would also be able to break up the chemically stable emulsified oil [2]. This treatment type is usually conducted as pre-treatment step before contaminated water and wastewater entering main treatment system such as membrane filtration or photo-catalysis treatment plant.

\subsection{Photocatalytic and oxidation processes}

Photocatalytic process is one of the outstanding techniques to enhance the quality of industrial wastewaters as it offers several advantages such as high efficiency, abundant energy sources like solar light, and simple application system, however, costly chemicals usage could be a main concern of this option [48]. This method can be classified into two main processes named homogeneous and heterogeneous processes that can be performed with or without the addition light irradiation. Several metal oxides such as $\mathrm{TiO}_{2}, \mathrm{ZnO}, \mathrm{MgO}_{3}, \mathrm{CeO}_{2}, \mathrm{ZrO} 2, \mathrm{SnO}_{2}, \mathrm{WO}_{3}, \alpha-\mathrm{FeO}_{3}, \mathrm{ZnS}, \mathrm{CdS}, \mathrm{CdSe}, \mathrm{WS}_{2}$, and $\mathrm{MgS}_{2}$ could be used as photocatalyst agents to succeed the treatment [49].

An investigation on restaurant wastewater containing oil and grease compounds treated using photo-catalytic with $\mathrm{TiO}_{2}$ addition reported that 10 min irradiation time was sufficient to achieve removal efficiencies of $\mathrm{COD}, \mathrm{BOD}_{5}$ and oil by $50 \%, 37 \%$, and $86 \%$, respectively [13].

Other oxidation processes named Fenton, Fenton-like, and photo Fenton have also been acknowledged as effective and efficient techniques. Fenton process is based on the use of chemicals known as Fenton's reagents $\left(\mathrm{Fe}^{2+} / \mathrm{H}_{2} \mathrm{O}_{2}\right)$ where the presence of $\mathrm{H}_{2} \mathrm{O}_{2}$ as an oxidizing agent in wastewater has a positive effect on the degradation rate of the organic pollutants due to more generation of hydroxyl radicals.

\subsection{Ozonation process}

Ozonation technique relies on the ozone molecule consisting of three negatively charged oxygen atoms to purify wastewater. Ozone could be artificially produced by oxygen generator to remove some pollutant particles including chlorinated hydrocarbons, pesticides, alcohol, ethers, microorganism and aromatic hydrocarbon [50,51]. A study conducted to treat oily wastewater generated by olive oil manufacturer using hybrid ozone and UV irradiation reported that more than $80 \%$ of phenol compounds can be removed while COD concentration could be reduced by $60 \%$ [52].

\subsection{Biological treatment methods}

Biological treatment involving the biological activities of microorganism to treat municipal and industrial wastewater offers some advantages such as being less expensive and non-toxic end products even though this process requires relatively larger plant area, and longer reaction time [5355]. This is generally applied as primary treatment along with other pretreatment process prior to hydrolyzing oil and grease. In terms of the need of oxygen for them to be active, bacteria used in this process could be aerobic, anaerobic, or both of them. Compared to aerobic, anaerobic treatment tends to generate more biogas and less biomass [56], though anaerobic treatment is still challenging as it could experience disintegration of sludge and limitation on bacteria efficiency due to the overload of oils and fats content [57]. 


\subsection{Integrated treatment methods}

It is believed that the application of integrated or multiple methods for treating oily wastewaters will result in better output as well as reduce the rate of machine breakage. Integrated or hybrid wastewater treatment is a prominent solution taken as preferred technology to get the highest quality of treated wastewater [58]. In integrated modes, two or more treatment techniques are applied in sequence. Therefore, some disadvantageous aspects of individual method can be covered by the benefit of other method and vice versa. There are two main parts which are included in an integrated treatment method namely pre-treatment and main treatment stages. In other words, it can include primary and secondary treatment processes [59]. Taking a membrane material as a prevalent example of a method that needs pre-treatment. By reducing the concentration of oil and grease, dissolved and suspended solid contained in the oily wastewater through pre-treatment process, membrane will perform better and longer to produce high quality permeate [22]. Raw wastewater can easily clog and produce fouling on membrane pore and surface leading to fast costly membrane material changing. Therefore, the implementation of some relevant pre-treatment on oily wastewater such as coagulation/flocculation, adsorption or advanced oxidation could elude more severe membrane fouling, reduce chemical cost, and lengthen membrane lifespan [60-66].

Along with other techniques, adsorption has been extensively applied as a pre-treatment stage to reduce targeted pollutant concentration as adsorbent enables those pollutant particles to be trapped in adsorbent's large surface area and abundant micro pores quantities [62,67]. This has been proved by some experimental investigations conducting the integration of powdered activated carbon and membrane filtration. They reported that adsorption process could reduce cake layer thickness on membrane pores yielding higher permeation flux and pollutant removal efficiency [28, 68]. Advanced oxidation process and coagulation could also be implemented as pre-treatment for oily wastewater derived from various industries including petroleum refinery as they could reduce dramatically any organic compounds and dissolved and suspended solids. [29]. After pre-treatment stage, purer industrial wastewater could enter membrane system leading to much lower fouling rate. Figure 2 illustrates an example of integrated wastewater treatment option involving Fenton and membrane filtration system.

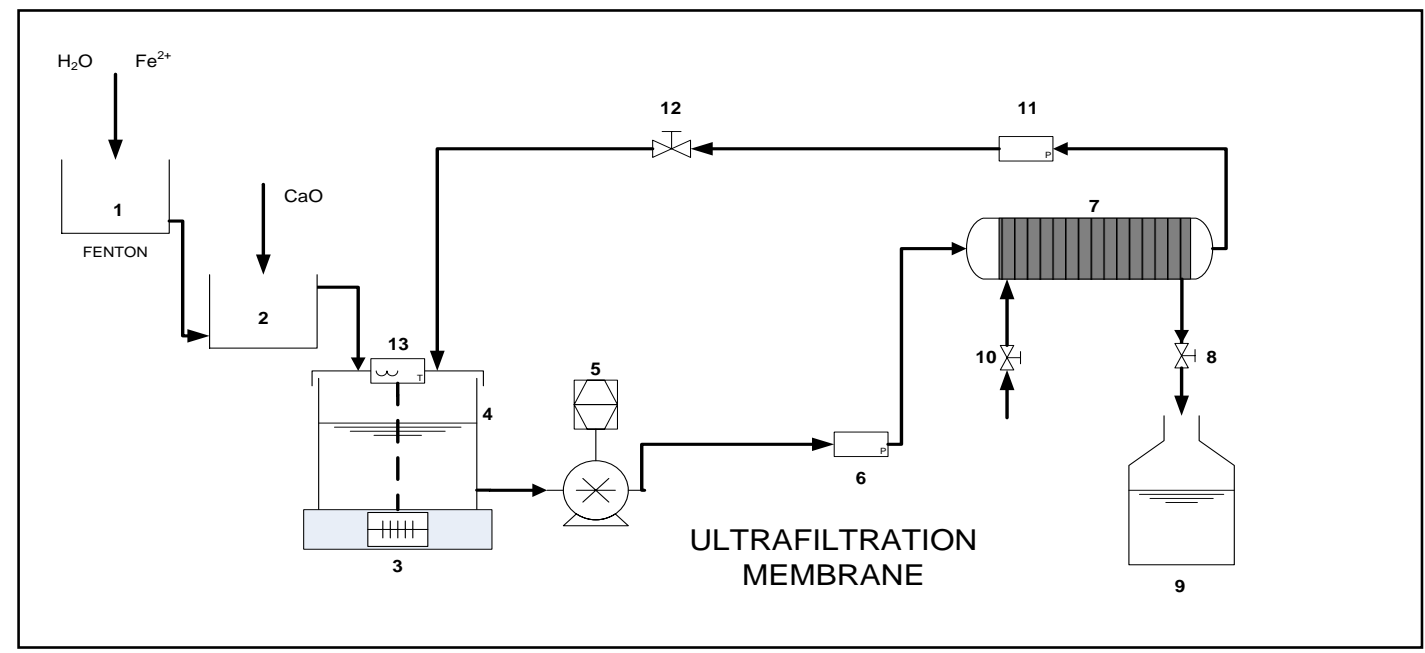

Fig. 2.Integrated membrane system involving pre-treatment process (1:Fenton batch, 2: Coagulation batch, 3 :

Magnetic stirrer, 4: Feed tank, 5: Digital peristaltic pump, 6: Pressure gauge, 7: Ultrafiltration membrane, 8: Permeate valve, 9: Permeate vessel, 10: Closed valve, 11: Pressure gauge, 12: Retentate valve, 12: Thermometer.

Dual membrane system can also be an alternative to keep membrane performance well. A combination of ultrafiltration and reverse osmosis membrane types for treating oily wastewater, for example, was reported working much better by experiencing only about $7 \%$ of permeate flux decline during filtration process [69]. However, it is undeniable that the main weakness of dual membrane treatment system is restricted to the high cost for initial constructing and maintaining works. 


\section{Conclusion}

This review article covers several prominent technologies for treating oily wastewater generated by various industrial sectors including edible oil manufacturers, petroleum refinery, and restaurant industries. As rapid industrialization has generated more amount of wastewater containing oil compounds threatening human health and environmental sustainability, the need of appropriate treatment methods such as membrane filtration, coagulation/flocculation, biological treatment using aerobic or anaerobic bacteria, adsorption, and relevant hybrid methods is unavoidable. These treatment technologies have to be implemented to increase the quality of industrial wastewaters before entering final disposal places. Among others, integrated wastewater treatment methods have been preferred as the best option as they offer better output and safer condition for machine and wastewater treatment plant system. Overall, by studying the existing relevant technology to treat an increasing number of oily wastewater sources, the quality of environment, human lives, and other living creatures will all be benefitted. It also supports the increasing trend of having less waste by doing recycling to support circular economy community as treated water and wastewater can be reused for further usage including irrigation, water process, and even drinking water.

\section{Notation}

$C O D=$ chemical oxygen demand, $\mathrm{mg} / \mathrm{L}$

$B O D=$ biological oxygen demand, $\mathrm{mg} / \mathrm{L}$

TOC = total organic carbon, $\mathrm{mg} / \mathrm{L}$

\section{Acknowledgment}

The authors would like to acknowledge the Department of Chemical Engineering, Universitas Muhammadiyah Palembang, Indonesia for great support during writing process of this review article.

\section{References}

[1] R. Wahi, L.A. Chuah, T.S.Y. Choong, Z. Ngaini, M.M. Nourouzi, Oil removal from aqueous state by natural fibrous sorbent: an overview, Separation and Purification Technology, 113 (2013) 51-63.

[2] P. Cañizares, F. Martínez, C. Jiménez, C. Sáez, M.A. Rodrigo, Coagulation and electrocoagulation of oil-in-water emulsions, Journal of Hazardous Materials, 151 (2008) 44-51.

[3] T. Ahmad, T. Belwal, L. Li, S. Ramola, R.M. Aadil, Abdullah, Y. Xu, L. Zisheng, Utilization of wastewater from edible oil industry, turning waste into valuable products: A review, Trends in Food Science \& Technology, 99 (2020) 21-33.

[4] P.F. Rupani, R.P. Singh, M.H. Ibrahim, N. Esa, Review of current palm oil mill effluent (POME) treatment methods: vermicomposting as a sustainable practice, World Applied Sciences Journal, 11 (2010) 70-81.

[5] E. Jenab, F. Temelli, J.M. Curtis, Y.-Y. Zhao, Performance of two immobilized lipases for interesterification between canola oil and fully-hydrogenated canola oil under supercritical carbon dioxide, LWT - Food Science and Technology, 58 (2014) 263-271.

[6] S. Martini, H.T. Znad, H.M. Ang, Photo-assisted fenton process for the treatment of canola oil effluent, Chemeca 2014: Processing excellence; Powering our future, (2014) 1519.

[7] A. El-Abbassi, A. Hafidi, M.C. García-Payo, M. Khayet, Concentration of olive mill wastewater by membrane distillation for polyphenols recovery, Desalination, 245 (2009) 670-674.

[8] A. El-Abbassi, H. Kiai, A. Hafidi, M.d.C. García-Payo, M. Khayet, Treatment of olive mill wastewater by membrane distillation using polytetrafluoroethylene membranes, Separation and Purification Technology, 98 (2012) 55-61.

[9] F.V. Santos, E.B. Azevedo, G.L. Sant'Anna Jr., M. Dezotti, Photocatalysis as a tertiary treatment for petroleum refinery wastewaters, Brazilian Journal of Chemical Engineering, 23 (2006) 451-460.

[10]L. Yan, H. Ma, B. Wang, W. Mao, Y. Chen, Advanced purification of petroleum refinery wastewater by catalytic vacuum distillation, Journal of Hazardous Materials, 178 (2010) 1120-1124. 
[11]A. Coelho, A.V. Castro, M. Dezotti, G.L. Sant'Anna Jr, Treatment of petroleum refinery sourwater by advanced oxidation processes, Journal of Hazardous Materials, 137 (2006) 178-184.

[12] A.L.N. Mota, L.F. Albuquerque, L.T.C. Beltrame, O. Chiavone-Filho, A.M. Jr., C.A.O. Nascimento, Advanced oxidation processes and their application in the petroleum industry: A review , Brazilian journal of petroleum and gas, 2 (2008).

[13]J.-x. Kang, L. Lu, W. Zhan, B. Li, D.-s. Li, Y.-z. Ren, D.-q. Liu, Photocatalytic pretreatment of oily wastewater from the restaurant by a vacuum ultraviolet/TiO2 system, Journal of Hazardous Materials, 186 (2011) 849-854.

[14] S. Zulaikha, W.J. Lau, A.F. Ismail, J. Jaafar, Treatment of restaurant wastewater using ultrafiltration and nanofiltration membranes, Journal of Water Process Engineering, 2 (2014) 58-62.

[15] S. Martini, S. Afroze, K. Ahmad Roni, Modified eucalyptus bark as a sorbent for simultaneous removal of COD, oil, and $\mathrm{Cr}(\mathrm{III})$ from industrial wastewater, Alexandria Engineering Journal, 59 (2020) 1637 1648 .

[16] J. Rubio, M.L. Souza, R.W. Smith, Overview of flotation as a wastewater treatment technique, Minerals Engineering, 15 (2002) 139-155.

[17] J.M. Benito, G. Rios, C. Pasoz, J. Coca, Methods for the separation of emulsified oil from water: a stateof-the-art review Trends Chemical Engineering, 4 (1998) 203-231.

[18]E.K. Dafnopatidou, N.K. Lazaridis, Dyes Removal from Simulated and Industrial Textile Effluents by Dissolved-Air and Dispersed-Air Flotation Techniques, Industrial \& Engineering Chemistry Research, 47 (2008) 5594-5601.

[19] S.E. Burns, S. Yiacoumi, C. Tsouris, Microbubble generation for environmental and industrial separations, Separation and Purification Technology, 11 (1997) 221-232.

[20]M. Abbasi, M. Mirfendereski, M. Nikbakht, M. Golshenas, T. Mohammadi, Performance study of mullite and mullite-alumina ceramic MF membranes for oily wastewaters treatment, Desalination, 259 (2010) 169-178.

[21]F.L. Hua, Y.F. Tsang, Y.J. Wang, S.Y. Chan, H. Chua, S.N. Sin, Performance study of ceramic microfiltration membrane for oily wastewater treatment, Chemical Engineering Journal, 128 (2007) 169175 .

[22]N.P. Cheremisinoff, Handbook of water and wastewater treatment technologies, ButterworthHeinemann, 2001.

[23] I.-S. Chang, C.-M. Chung, S.-H. Han, Treatment of oily wastewater by ultrafiltration and ozone, Desalination, 133 (2001) 225-232.

[24] S.S. Madaeni, H. Ahmadi Monfared, V. Vatanpour, A. Arabi Shamsabadi, E. Salehi, P. Daraei, S. Laki, S.M. Khatami, Coke removal from petrochemical oily wastewater using $\gamma$-Al2O3 based ceramic microfiltration membrane, Desalination, 293 (2012) 87-93.

[25] A.L. Ahmad, S.Y. Chan, Sustainability of Palm Oil Industries: An Innovative Treatment via Membrane Technology, Journal of Applied Sciences, 9 (2009).

[26] S. Martini, E. Yuliwati, D. Kharismadewi, Teknologi pengolahan limbah cair industry, Jurnal Distilasi, 5 (2020) 26-33.

[27]T. Mohammadi, A. Esmaeelifar, Wastewater treatment using ultrafiltration at a vegetable oil factory, Desalination, 166 (2004) 329-337.

[28] T. Mohammadi, A. Esmaeelifar, Wastewater treatment of a vegetable oil factory by a hybrid ultrafiltration-activated carbon process, Journal of Membrane Science, 254 (2005) 129-137.

[29] S. Martini, H.M. Ang, H. Znad, Integrated ultrafiltration membrane unit for efficient petroleum refinery effluent treatment, Clean Soil Air Water, 45 (2017) 1-9.

[30] S. Martini, Development of an Efficient Integrated System for Industrial Oily Wastewater Treatment, in, Curtin University, 2016. 
[31] W.J. Weber, C.B. Beck, Physicochemical processes for water quality control, Walter J. Weber, Jr. (with eight contributors), Interscience, New York (1972). 640 pages. \$19.95, AIChE Journal, 19 (1973) 413413.

[32]A. Bhatnagar, M. Sillanpää, Utilization of agro-industrial and municipal waste materials as potential adsorbents for water treatment — a review, Chemical Engineering Journal, 157 (2010) 277-296.

[33]N. Khalid, S. Ahmad, A. Toheed, J. Ahmed, Potential of rice husks for antimony removal, Applied Radiation and Isotopes, 52 (2000) 31-38.

[34] B.H. Hameed, D.K. Mahmoud, A.L. Ahmad, Equilibrium modeling and kinetic studies on the adsorption of basic dye by a low-cost adsorbent: Coconut (Cocos nucifera) bunch waste, Journal of Hazardous Materials, 158 (2008) 65-72.

[35] S. Ibrahim, S. Wang, H.M. Ang, Removal of emulsified oil from oily wastewater using agricultural waste barley straw, Biochemical Engineering Journal, 49 (2010) 78-83.

[36] V. Rajakovic, G. Aleksic, M. Radetic, L. Rajakovic, Efficiency of oil removal from real wastewater with different sorbent materials, Journal of Hazardous Materials, 143 (2007) 494-499.

[37]X.F. Sun, R.C. Sun, J.X. Sun, Acetylation of sugarcane bagasse using NBS as a catalyst under mild reaction conditions for the production of oil sorption-active materials, Bioresource Technology, 95 (2004) 343-350.

[38] A. Srinivasan, T. Viraraghavan, Removal of oil by walnut shell media, Bioresource Technology, 99 (2008) 8217-8220.

[39] A.L. Ahmad, S. Sumathi, B.H. Hameed, Adsorption of residue oil from palm oil mill effluent using powder and flake chitosan: Equilibrium and kinetic studies, Water Research, 39 (2005) 2483-2494.

[40] S. Suni, A.L. Kosunen, M. Hautala, A. Pasila, M. Romantschuk, Use of a by-product of peat excavation, cotton grass fibre, as a sorbent for oil-spills, Marine Pollution Bulletin, 49 (2004) 916-921.

[41] W. Ngarmkam, C. Sirisathitkul, C. Phalakornkule, Magnetic composite prepared from palm shell-based carbon and application for recovery of residual oil from POME, Journal of Environmental Management, 92 (2011) 472-479.

[42]R. Wahi, L.A. Chuah, Z. Ngaini, M.M. Nourouzi, T.S.Y. Choong, Esterification of M. sagu bark as an adsorbent for removal of emulsified oil, Journal of Environmental Chemical Engineering, 2 (2014) 324331.

[43]H. Moriwaki, S. Kitajima, M. Kurashima, A. Hagiwara, K. Haraguchi, K. Shirai, R. Kanekatsu, K. Kiguchi, Utilization of silkworm cocoon waste as a sorbent for the removal of oil from water, Journal of Hazardous Materials, 165 (2009) 266-270.

[44] S. Martini, S. Afroze, K.A. Roni, Modified eucalyptus bark as a sorbent for simultaneous removal of COD, oil, and Cr (III) from industrial wastewater, Alexandria Engineering Journal, (2020).

[45]J.E. Drinan, F. Spellman, Water and Wastewater Treatment: A Guide for the Nonengineering Professional, Second Edition, CRC Press, 2012.

[46]D. Ghernaout, The hydrophilic/hydrophobic ratio vs. dissolved organics removal by coagulation - A review, Journal of King Saud University - Science, 26 (2014) 169-180.

[47]R.S. J., Organic Contaminant Removal by Coagulation and Related Process Combinations, Journal American Water Works Association, 80 (1988) 40-56.

[48] T.-D. Nguyen-Phan, E.W. Shin, Morphological effect of TiO2 catalysts on photocatalytic degradation of methylene blue, Journal of Industrial and Engineering Chemistry, 17 (2011) 397-400.

[49]N. Serpone, P. Maruthamuthu, P. Pichat, E. Pelizzetti, H. Hidaka, Exploiting the interparticle electron transfer process in the photocatalysed oxidation of phenol, 2-chlorophenol and pentachlorophenol: chemical evidence for electron and hole transfer between coupled semiconductors, Journal of Photochemistry and Photobiology A: Chemistry, 85 (1995) 247-255.

[50]M. Mehrjouei, S. Müller, D. Möller, A review on photocatalytic ozonation used for the treatment of water and wastewater, Chemical Engineering Journal, 263 (2015) 209-219. 
[51] V. Lazarova, A. Bahri, Water Reuse for Irrigation: Agriculture, Landscapes, and Turf Grass, CRC Press, 2004.

[52]P. Karageorgos, A. Coz, M. Charalabaki, N. Kalogerakis, N.P. Xekoukoulotakis, D. Mantzavinos, Ozonation of weathered olive mill wastewaters, Journal of Chemical Technology \& Biotechnology, 81 (2006) 1570-1576.

[53]H. Lemmer, M. Baumann, Scum actinomycetes in sewage treatment plants-Part 2: The effect of hydrophobic substrate, Water Research, 22 (1988) 761-763.

[54]E. Forgacs, T. Cserháti, G. Oros, Removal of synthetic dyes from wastewaters: a review, Environment International, 30 (2004) 953-971.

[55] G. Crini, Non-conventional low-cost adsorbents for dye removal: A review, Bioresource technology, 97 (2006) 1061-1085.

[56] S.E. Manahan, Fundamentals of Environmental Chemistry, Second Edition, Taylor \& Francis, 2010.

[57] Y.-B. Zhou, X.-Y. Tang, X.-M. Hu, S. Fritschi, J. Lu, Emulsified oily wastewater treatment using a hybrid-modified resin and activated carbon system, Separation and Purification Technology, 63 (2008) 400-406.

[58]J. Wang, X. Tang, Y. Xu, X. Cheng, G. Li, H. Liang, Hybrid UF/NF process treating secondary effluent of wastewater treatment plants for potable water reuse: Adsorption vs. coagulation for removal improvements and membrane fouling alleviation, Environmental Research, 188 (2020) 109833.

[59] A. Ullah, S. Hussain, A. Wasim, M. Jahanzaib, Development of a decision support system for the selection of wastewater treatment technologies, Science of The Total Environment, 731 (2020) 139158.

[60] A. Babuponnusami, K. Muthukumar, A review on Fenton and improvements to the Fenton process for wastewater treatment, Journal of Environmental Chemical Engineering, 2 (2014) 557-572.

[61]L.M. Nieto, G. Hodaifa, S. Rodríguez, J.A. Giménez, J. Ochando, Degradation of organic matter in olive-oil mill wastewater through homogeneous Fenton-like reaction, Chemical Engineering Journal, 173 (2011) 503-510.

[62] J. Coca-Prados, G. Gutiérrez, J. Benito, Treatment of Oily Wastewater by Membrane Hybrid Processes, in: J. Coca-Prados, G. Gutiérrez-Cervelló (Eds.) Economic Sustainability and Environmental Protection in Mediterranean Countries through Clean Manufacturing Methods, Springer Netherlands, 2013, pp. 3561.

[63] M. Gryta, K. Karakulski, A.W. Morawski, Purification of oily wastewater by hybrid UF/MD, Water research, 35 (2001) 3665-3669.

[64]M. Karhu, T. Kuokkanen, J. Rämö, M. Mikola, J. Tanskanen, Performance of a commercial industrialscale UF-based process for treatment of oily wastewaters, Journal of environmental management, 128 (2013) 413-420.

[65] S. Martini, H.M. Ang, Hybrid TiO2/UV/PVDF ultrafiltration membrane for raw canola oil wastewater treatment, Desaliantion and water treatment, 148 (2019) 51-59.

[66] S. Martini, Pengolahan limbah cair minyak kanola menggunakan kombinasi adsorpsi dan membran ultrafiltrasi polimer, Kinetika, 10 (2019) 36-41.

[67] S. Jamaly, A. Giwa, S.W. Hasan, Recent improvements in oily wastewater treatment: Progress, challenges, and future opportunities, Journal of Environmental Sciences, 37 (2015) 15-30.

[68] M.V. Sarfaraz, E. Ahmadpour, A. Salahi, F. Rekabdar, B. Mirza, Experimental investigation and modeling hybrid nano-porous membrane process for industrial oily wastewater treatment, Chemical Engineering Research and Design, 90 (2012) 1642-1651.

[69]M. Tomaszewska, A. Orecki, K. Karakulski, Treatment of bilge water using a combination of ultrafiltration and reverse osmosis, Desalination, 185 (2005) 203-212. 